\title{
Development of a Small Hydropower Plant: Case of Ikere Gorge Dam, Oyo State, Nigeria
}

\author{
Moradeyo K. Odunfa1 ${ }^{*}$, Timiepiri C. Saudu1, Temitayo E. Oladimeji² \\ ${ }^{1}$ Mechanical Engineering Department, University of Ibadan, Ibadan, Nigeria \\ ${ }^{2}$ Chemical Engineering Department, Covenant University, Ota, Nigeria \\ Email: ^m.odunfa@mail.ui.edu.ng, ${ }^{\star} 1$ stclem@gmail.com
}

How to cite this paper: Odunfa, M.K., Saudu, T.C. and Oladimeji, T.E. (2019) Development of a Small Hydropower Plant: Case of Ikere Gorge Dam, Oyo State, Nigeria. Journal of Power and Energy Engineering, 7, 31-45.

https://doi.org/10.4236/jpee.2019.73003

Received: March 29, 2018

Accepted: March 26, 2019

Published: March 29, 2019

Copyright $\odot 2019$ by author(s) and Scientific Research Publishing Inc. This work is licensed under the Creative Commons Attribution International License (CC BY 4.0).

http://creativecommons.org/licenses/by/4.0/

(c) (i) Open Access

\begin{abstract}
Energy crisis and environmental safety has become a thing of global concern, Nigeria inclusive. This is due to the increasing energy prices and environmental impact. Energy generated from the non-renewable energy sources has been linked up with this energy crisis and non-friendly environment. Research is therefore been geared towards harnessing renewable energy resources as alternative sources of energy generation. Renewable energy sources such as hydropower, wind, geothermal and solar just to mention a few are environmentally friendly. This study therefore aims at exploring renewable energy sources and thus designing a small hydropower plant using Ikere gorge Dam as case study. A survey was conducted through personal interview and probing of previous records of the site. Basic parameters such as flow rate of $31.8 \mathrm{~m}^{3} / \mathrm{s}$ and a head of $30 \mathrm{~m}$ were obtained. These parameters were used together with the standard equations for the design of the small hydropower plant. Costing analysis of the plant was carried out in other to estimate the cost of the plant. The comparative analysis of the renewable and non-renewable energy sources was also carried out. The theoretical power obtained for small hydropower project is $9.36 \mathrm{MW}$. The initial cost of the project is estimated at N63,343,970 with an estimated annual maintenance cost of N500,000. The annual energy output is $3.6 \times 10^{7} \mathrm{kWh}$ and the project has estimated annual revenue of $\mathrm{N} 579,960,000$. When compared with other renewable energy sources, the cost of small hydropower plant is low and when compared with dwindling oil prices and environmental effects of non-renewable energy sources, small hydropower stands second to none. The study established that Ikere gorge Dam is a feasible site for a small hydropower plant and a small hydropower plant has also been designed; hence small hydropower plant is therefore recommended.
\end{abstract}

\section{Keywords}

Renewable Energy, Non-Renewable Energy, Environmental Safety, Ikere Gorge 


\section{Introduction}

Energy conversion and power generation has been a paramount and ever-evolving activity of man for several centuries. From simple wind-powered threshing mills, to coal-powered steam engines, power generation from natural gas, oil, renewable energy sources, and in recent time nuclear energy, man has constantly tried to improve. For developed countries, emphasis is laid on transition from non-renewable sources of energy to renewable sources with the aim of taming greenhouse effect and depletion of the ozone layer. For developing countries, such as Nigeria, it is a different ball game all together. Enough power is not being generated, let alone talks of transition. According to the Presidential Task Force on Power, "Nigerians are among the people most deprived of grid-based electricity in the world with a per capital consumption that is far lower than many other African countries". Nigeria currently has the capacity to generate about 6000 megawatts of electricity of which only 3600 is being generated for a populace of over 160 million.

What this means is that about 22.8 Watts of electricity is produced for each Nigerian per capita. For all things being equal, Nigeria has the capacity to generate enough power to meet the power consumption needs of the populace. Small hydropower (SHP) is a proven technology that can stand-alone, being connected to an isolated grid, or the national grid. In most cases, it is often combined with irrigation systems. One of the major industrial problems in Nigeria is power generation. Sufficient power is not being generated to cater for industry needs, as well as the needs of the populace. Nigeria has the capacity to produce enough power to cater for the needs to industries and the populace at large. Aside being blessed with crude oil, solid minerals, and workforce, Nigeria is blessed with sufficient water bodies. While power from gas, steam, and coal is prevalent, the adverse effect of their usage cannot be overruled. Hydropower can contribute immensely in tackling the power situation in Nigeria. The bottom line is that SHP can adequately contribute to the electricity needs of Nigeria. Statistics prove that Nigeria is blessed with enough water bodies that can contribute substantially to power generation output. The exploitable hydropower potential in Nigeria is conservatively estimated to be about $10,000 \mathrm{MW}$ [1] and only about $19 \%$ is currently been tapped or developed. The hydropower potential in Nigeria accounts for about $29 \%$ of the total electrical supply [2]. As at 2005, Nigeria had the capacity to produce $734.2 \mathrm{MW}$ of electricity from SHP, but only $30 \mathrm{MW}$ was being produced, which is less than $5 \%$ of what can be produced [3]. This work therefore aims at adding to the repertoire of knowledge and specifically designed small hydropower plant capable of supplying electricity for a small community using Ikere water gorge in Nigeria as a case study. Electricity generation is closely tied to economic, industrial and educational development. About 1.7 billion people do not have access to electricity [4]. If the issue of electricity is properly and effectively handled, there's bound to be productivity in every aspect of the economy. If every community can handle its own power needs, the power supply 
from the national grid can be directed to major cities. Small hydropower has grown to become accepted as an inexpensive, easy to develop, and environmentally friendly source of energy. All of these benefits have increased the value of SHP options and have pioneered recent trends in renewable energy generation [5]. Hydropower is power or energy gotten from water. Flowing water at an elevation possesses the two forms of mechanical energy: potential and kinetic energies. Hydropower has long been harnessed prior to the widespread availability of commercial electric power. Over 2000 years ago, the Greeks used water wheels to grind wheat to flow [6] (US Department of Energy, 2008). Other ancient uses included irrigation, operation of textile machines, watermills, and sawmills. The concept of hydro-electricity became wide spread in the late $19^{\text {th }}$ century with the coupling of waterwheels with electrical generators. As at the dawn of the $20^{\text {th }}$ century, many towns, industries, and cities located near rivers had harnessed hydropower. In a country like the United States, as at 1920 , about $40 \%$ of the power produced was from hydropower. This wide spread popularity gave hydropower the nickname "white coal" [7]. At the early stages of the development of hydropower plants, they were relatively more reliable and efficient than fossil fuel-powered plants [8]. This can be held accountable for the proliferation of small and medium-sized hydropower plants wherever there was sufficient moving water and a need for electricity. As the population of the world increased, the demand for electricity grew, leading to an increased number and size of fossil fuel, hydropower, and even nuclear power plants. In recent years due to the size of hydropower plants, associated dams and reservoirs have been developed with additional uses such as irrigation, recreation, navigation, flood control, and water supply. Conversely, hydropower plants have been incorporated to dams that were originally built for irrigation, water supply, and flood control. Despite the seemingly high potential of hydropower, it accounts for about $16.3 \%$ of the world's electricity, which is lesser than power generated from fossil fuels. Fossil fuel plants account for about $67.2 \%$ of the world's electricity. However, power generated from hydro is higher than nuclear, wind, solar, geothermal, and other sources of power combined [9]. Concerns about the environment and social impact of using fossil fuels have considerably increased in the last decades. These concerns have lead to increased campaigns on shifting towards greener and more environmental energy source. As earlier stated hydropower provides the largest share of renewable electricity worldwide and still has enormous potential for future development. As at today, hydropower plants span from few Watts to several Gigawatts. The largest projects are Itaipu in Brazil (14,000 MW) and Three Gorges in China (22,400 MW).

\section{Mechanism of Hydropower}

The definition of small hydropower varies from country to country, as there is no internationally accepted value. In a country like Sweden, the limit is $1.5 \mathrm{MW}$, in India $15 \mathrm{MW}$, and in China, small hydropower encompasses capacities up to 
25 MW. However, $10 \mathrm{MW}$ is generally accepted as the threshold for small hydropower by European Small Hydropower Association, European Commission, and International Union of Producers and Distributors of Electricity [10]. Small hydropower projects can be further broken down as; mini, micro, and pico hydropower depending on the installed capacity. These limits are $1 \mathrm{MW}, 100 \mathrm{~kW}$, and $16 \mathrm{~kW}$ for mini, micro, and pico hydropower, respectively [11]. Table 1 shows hydropower definitions according to ECOWAS.

The $30 \mathrm{MW}$ limit for small hydropower was because all the projects in the considered region were added up (ECREEE, 2012).

\subsection{Advantages and Disadvantages of Small Hydropower Plant}

[10] stated that "SHP meets the needs of the present without compromising the ability of future generations to meet their own needs." What this means is that small hydropower is sustainable. When compared with other sources of power, small hydropower ranks amongst the cheapest. Aside the fact that SHP has high untapped potential, especially in developing countries, its technology is open to new technological developments. Another major advantage is its flexibility and reliability, as well as its independence on the fuel costs. It has fast start up and shutdown response time [12]. According to [13], “one GWh of electricity produced by small hydropower means a reduction of 480 tonnes of emitted carbon dioxide". What this implies is that, when compared with other sources of electricity, small hydropower is very much environmental friendly. In addition, small hydropower schemes have long life spans and after building and installations, the associated cost and frequency of maintenance are minimal [14]. Small hydropower plants however do not come without disadvantages. One of such disadvantage is the effect of small hydropower schemes on fishes. Weir and intake structures disrupt the movement of fishes. There is also the possibility of fishes being killed by the turbine blades or gas bubbles from supersaturated water. Another disadvantage is variation in energy production due to seasonal variations in flow. Unlike other sources which have more stable and fixed electricity generation capacity, variations in flow (during low flow seasons) limit electricity generation [14].

Table 1. Definition of hydropower.

\begin{tabular}{|c|c|c|}
\hline Terms & & Power Output \\
\hline Pico Hydropower & Small & $<5 \mathrm{~kW}$ \\
\hline Micro Hydropower & $\begin{array}{c}\text { Scale } \\
\text { Hydropower }\end{array}$ & $5 \mathrm{~kW}-100 \mathrm{~kW}$ \\
\hline Mini Hydropower “MHP” & “SSHP” & $100 \mathrm{~kW}-1000 \mathrm{~kW}(1 \mathrm{MW})$ \\
\hline Small Hydropower "SHP” & & $1 \mathrm{MW}-30 \mathrm{MW}$ \\
\hline Medium Hydropower & & $30 \mathrm{MW}-100 \mathrm{MW}$ \\
\hline Large Hydropower "LHP” & & $>100 \mathrm{MW}$ \\
\hline
\end{tabular}




\subsubsection{Small Hydropower in the World}

Small hydropower contributes immensely to the worlds' renewable energy sources because it is cheap and provides clean energy. Table 2 shows the global contribution of each renewable energy source.

Going by the definition of small hydropower being between $1 \mathrm{MW}-10 \mathrm{MW}$, as at 2004, the total globally installed small hydropower plants produced about 48 Gigawatts (GW), as shown in Table 3. China is one of the worlds' largest users of small hydropower. As at 2005, China had reached a power production capacity of 31,200 MW which accounts for more than half of what is being produced worldwide [11]. Despite this promising figure, there are still several untapped small hydropower potential in several countries and continents, especially in Africa and Asia. In Canada moves have been made to replace diesel generators by SHP in remote, off-grid regions [10] (Figure 1).

\subsubsection{Small Hydropower in Nigeria}

As stated in preceding sections, economic development of a country is closely tied to its ability to provide enough power to cater for the domestic and industrial needs of the populace. In Nigeria however, the demand for power far

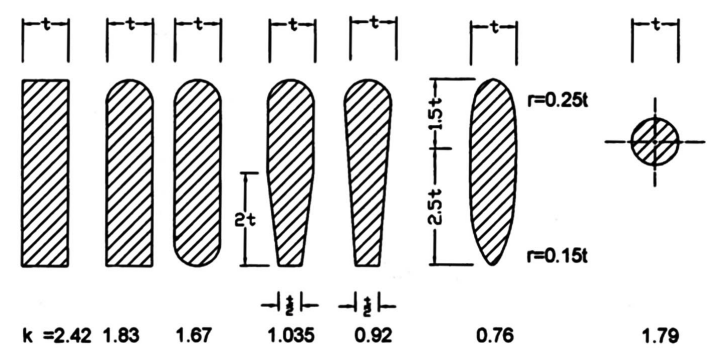

Figure 1. Value of K for different bar shapes (BIS, 2012).

Table 2. Global contribution by each renewable energy source [12].

\begin{tabular}{cc}
\hline Energy Source & Percentage \\
\hline Large hydro $(>10 \mathrm{MW})$ & $86 \%$ \\
Small hydro $(<10 \mathrm{MW})$ & $8.3 \%$ \\
Wind and solar & $0.6 \%$ \\
Geothermal & $1.6 \%$ \\
Biomass & $3.5 \%$ \\
\hline
\end{tabular}

Table 3. Installed SHP (<10 MW) capacity by world region in 2004 [11].

\begin{tabular}{ccc}
\hline Region & Capacity (MW) & Percentage (\%) \\
\hline Asia & 32,641 & 68.0 \\
Europe & 10,723 & 22.3 \\
North America & 2929 & 6.1 \\
South America & 1280 & 2.7 \\
Africa & 228 & 0.5 \\
Australasia & 198 & 0.4 \\
\hline
\end{tabular}


outstrips the power being generated and supplied. Nigeria has numerous potential sites for SHP. Harnessing these options will go a long way in changing the power production level in Nigeria. Between 2003 and 2007, Nigeria experienced a growth in hydropower of 9.7\% [15]. As at 2005, although Nigeria had the capacity to produce 734.2 MW of electricity from SHP, only 30 MW was being produced, which is less that $5 \%$ of what can be produced [3] (ECN-UNDP RE Master Plan, 2005). Owing to the fact that most Nigerian communities have SHP potentials, power generated from SHP projects can be used to supply electricity for lighting, information and communications technology, and processing of agricultural produce. The underlying assumption is that these SHP projects can sufficiently provide power for rural communities, while feeding the excess to the national grid. According to the National Agency for Science and Engineering Infrastructure (NASENI) SHP capacity in Nigeria can reach $3500 \mathrm{MW}$, accounting for about $23 \%$ of the country's entire hydropower capacity [16]. Table 4 [17] reveals potential sites for SHP projects in Nigeria.

\section{Data, Equations and Calculation}

Results were obtained using the standard hydropower equations with the data obtained from the site (Ikere gorge Dam) coupled with some other fundamental fluid property values [18]. The Aerial view of Ikere gorge dam site using Google maps is as shown in Figure 2 and Figure 3. The analysis done to obtain the results is as follows.

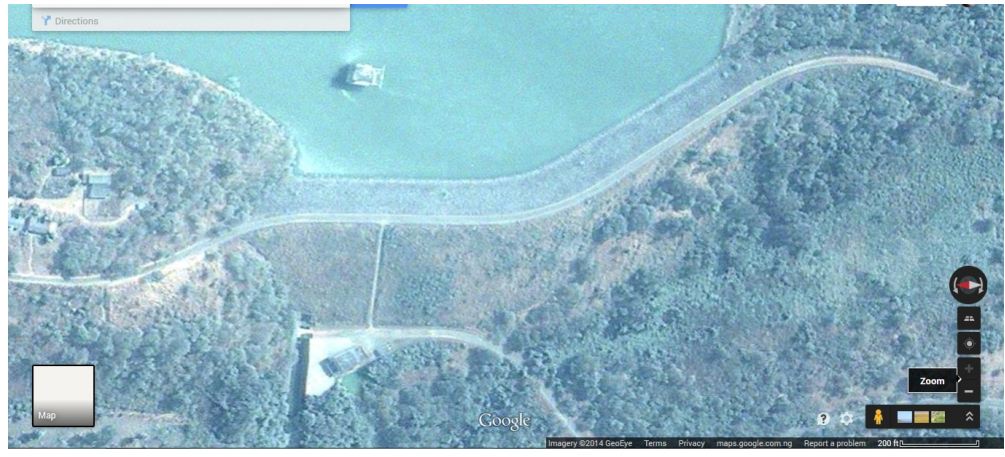

Figure 2. Aerial view of Ikere gorge dam using Google maps.

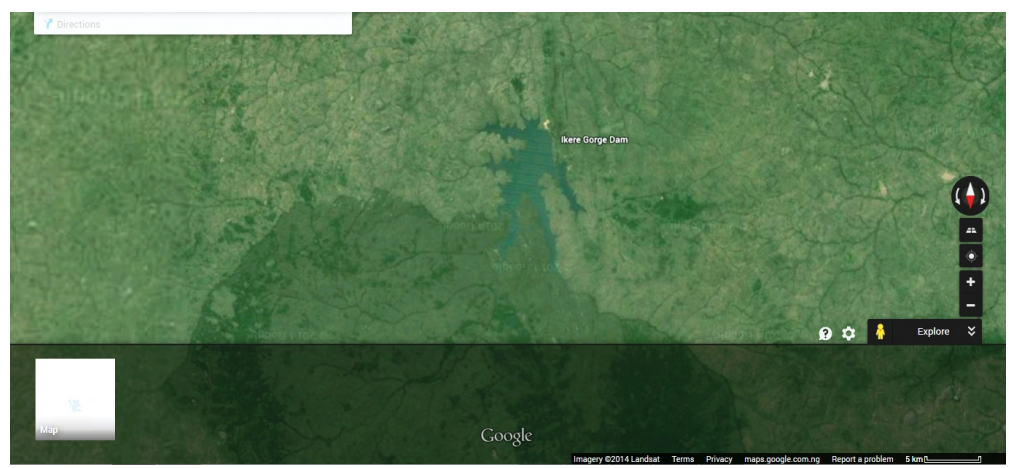

Figure 3. Aerial view of Ikere gorge dam using Google maps. 
Table 4. Summary of small hydropower potential sites in Nigeria [17].

\begin{tabular}{|c|c|c|}
\hline State & Potential Sites & Estimated output \\
\hline Adamawa & 3 & 28.600 \\
\hline Akwa Ibom & 13 & \\
\hline Bauchi & 1 & 0.150 \\
\hline Benue & 10 & 1.306 (one site) \\
\hline Cross River & 5 & 3.0 \\
\hline Delta & 1 & 1.0 \\
\hline Ebonyi & 5 & 1.3999 \\
\hline Edo & 5 & 3.828 \\
\hline Ekiti & 6 & 1.2472 \\
\hline Enugu & 1 & \\
\hline FCT & 6 & \\
\hline Gombe & 2 & 35.099 \\
\hline Imo & 71 & \\
\hline Kaduna & 15 & 25.0 \\
\hline Kano & 2 & 14.0 \\
\hline Katsina & 11 & 234.34 \\
\hline Kebbi & 1 & \\
\hline Kogi & 2 & 1.055 \\
\hline Kwara & 4 & 5.2 \\
\hline Nassarawa & 3 & 0.454 \\
\hline Niger & 11 & 110.580 \\
\hline Ogun & 13 & 115.610 \\
\hline Ondo & 1 & 1.3 \\
\hline Osun & 8 & 2.622 \\
\hline Oуо & 3 & 1.062 \\
\hline Plateau & 14 & 89.1 \\
\hline Sokoto & 1 & \\
\hline Taraba & 9 & 134.720 \\
\hline Yobe & 5 & \\
\hline Zamfara & 16 & \\
\hline
\end{tabular}

\section{Theoretical Power $\left(P_{t h}\right)$}

The theoretical power is the maximum power that can be generated from the hydropower project. The assumption is that the efficiency of the system is $100 \%$, as well as no head losses.

The theoretical power is calculated using equation below

$$
P_{t h}=\eta \rho g Q H
$$




$$
\begin{aligned}
& \eta=1 \\
& \rho=1000 \mathrm{~kg} / \mathrm{m}^{3} \\
& g=9.81 \mathrm{~m} / \mathrm{s}^{2} \\
& Q=31.8 \mathrm{~m}^{3} / \mathrm{s} \\
& H=30 \mathrm{~m} \\
& \text { Therefore, }
\end{aligned}
$$

$$
P_{t h}=1 \times 1000 \times 9.81 \times 31.8 \times 30=9.36 \mathrm{MW}
$$

\section{Penstock}

\section{Penstock Diameter $(D)$}

Selection of the diameter size of a penstock is interplay between limiting head losses and reducing the cost of the penstock. The head losses decrease as the penstock diameter increases. On the contrary, the cost of penstock increases with an increase in diameter.

The penstock diameter is calculated such that the overall head loss is limited to $4 \%$. This is given by Equation (3.3) as.

$$
D=2.69\left(\frac{n^{2} Q^{2} L}{H_{\text {gross }}}\right)^{0.1875}
$$

$$
\begin{aligned}
& n=0.009 \text { for } \mathrm{PVC} \\
& Q=31.8 \mathrm{~m}^{3} / \mathrm{s} \\
& L=100 \mathrm{~m} \\
& H_{\text {gross }}=30 \mathrm{~m}
\end{aligned}
$$

$$
D=2.69\left(\frac{0.009^{2} \times 31.8^{2} \times 100}{30}\right)^{0.1875}=2.1 \mathrm{~m}
$$

When the head losses-loss at intake, loss at trash rack, frictional losses, losses through bends, and loss at gate valve were calculated using this value $(2.1 \mathrm{~m})$, it was discovered that the total head losses exceeding the acceptable range limit of 4\%. Different values of $D$ were computed-2.1 m, $2.2 \mathrm{~m}, 2.3 \mathrm{~m}, 2.4 \mathrm{~m}, 2.5 \mathrm{~m}$, and $2.6 \mathrm{~m}$. At $2.6 \mathrm{~m}$, the total head loss was within the limit of $4 \%$.

Hence, $D=2.6 \mathrm{~m}$

\section{Minimum Thickness $\left(t_{\min }\right)$}

$$
t_{\min }=2.5 D+1.2=2.5 \times 2.6+1.2=7.7 \mathrm{~mm}
$$

A supplier recommended $15 \mathrm{~mm}$, hence the choice for a penstock thickness of $15 \mathrm{~mm}$.

Velocity in Penstock $(V)$

$V=Q / A$

$Q=31.8 \mathrm{~m}^{3} / \mathrm{s}$

$A=3.142 \times 2.6^{2} / 4=5.31 \mathrm{~m}^{2}$

$$
V=\frac{31.8}{5.31}=5.99 \mathrm{~m}^{-s}
$$

\section{Head Loss at Intake $\left(h_{i}\right)$}




$$
h_{i}=\frac{k V^{2}}{2 g}
$$

$K$ is a constant and is given as 0.04 for this design

$V=5.99 \mathrm{~m} / \mathrm{s}$

$g=9.81 \mathrm{~m} / \mathrm{s}^{2}$

$$
h_{i}=\frac{0.04 \times 5.99^{2}}{2 \times 9.81}=0.073 \mathrm{~m}
$$

\section{Frictional Loss $\left(\boldsymbol{h}_{f}\right)$}

The frictional loss is given by equation

$$
\frac{h_{f}}{L}=10.3 \frac{n^{2} Q^{2}}{D^{5.333}}
$$

$L=100 \mathrm{~m}$

$n=0.009$

$Q=31.8 \mathrm{~m}^{3} / \mathrm{s}$

$D=2.6 \mathrm{~m}$

$$
h_{f}=10.3 \frac{0.009^{2} \times 31.8^{2} \times 100}{2.6^{5.333}}=0.517 \mathrm{~m}
$$

\section{Head Loss at Bend $\left(h_{b}\right)$}

$$
h_{b}=\frac{K_{b} V^{2}}{2 g}
$$

$K_{b}$ is a constant and is given as 0.085 for this design

$V=5.99 \mathrm{~m} / \mathrm{s}$

$$
g=9.81 \mathrm{~m} / \mathrm{s}^{2}
$$

$$
h_{b}=\frac{0.085 \times 5.99^{2}}{2 \times 9.81}=0.155 \mathrm{~m}
$$

\section{Loss at Gate Valve $\left(h_{v}\right)$}

$$
h_{v}=\frac{K_{v} V^{2}}{2 g}
$$

$\mathrm{K}_{\mathrm{v}}$ is a constant and is given as 0.15 for fully opened gate valve

$$
h_{v}=\frac{0.15 \times 5.99^{2}}{2 \times 9.81}=0.274 \mathrm{~m}
$$

\section{Pressure Wave Velocity (c)}

The surge pressure wave velocity is given by Equation (3.8)

$$
c=\sqrt{\frac{10^{-3} K}{1+\frac{K D}{E t}}}
$$

$$
\begin{aligned}
& K=2.1 \times 10^{9} \mathrm{~N} / \mathrm{s}^{2} \\
& E=2.75 \times 10^{9} \mathrm{~N} / \mathrm{m}^{2} \\
& D=2600 \mathrm{~mm} \\
& t=15 \mathrm{~mm}
\end{aligned}
$$




$$
c=\sqrt{\frac{2.1 \times 10^{6}}{1+\frac{2.1 \times 10^{9} \times 2600}{2.75 \times 10^{9} \times 15}}}=125.49 \mathrm{~m} / \mathrm{s}
$$

Critical Time (T)

$$
\begin{gathered}
T=\frac{2 L}{c} \\
P_{s}=\frac{2 \times 100}{125.49}=1.59 \text { seconds }
\end{gathered}
$$

\section{Surge Pressure in Penstock $\left(p_{s}\right)$}

The surge pressure is given as:

$$
\begin{gathered}
P_{s}=\frac{4 c}{9.8} \\
P_{s}=\frac{4 \times 125.49}{9.8}=51.22 \mathrm{~m}
\end{gathered}
$$

\section{Trash Rack}

\section{Surface Area $(S)$}

The surface area of the trash rack is as given below:

$$
S=\frac{1}{K_{1}}\left(\frac{b+a}{a}\right) \frac{Q}{V_{0}} \frac{1}{\sin \alpha}
$$

$K_{1}=0.85$ for an automatic raker

$b=70 \mathrm{~mm}$

$a=60 \mathrm{~mm}$

The approach velocity, $V_{0}$ is limited to $1.5 \mathrm{~m} / \mathrm{s}$ since there are plans to make use of mechanical raking system.

$\alpha=60^{\circ}$

$$
S=\frac{1}{0.85}\left(\frac{70+60}{60}\right) \frac{31.8}{1.5} \frac{1}{\sin 60}=62 \mathrm{~m}^{2}
$$

\section{Head Loss through Trash Rack $\left(h_{t}\right)$}

$$
h_{t}=K_{s}\left[\frac{t_{b}}{b}\right]^{\frac{4}{3}} \times \frac{v_{0}^{2}}{2 g} \sin \alpha
$$

$K_{s}=1.67$ for flat bar with rounded ends as seen in Figure 1

$t_{b}=12 \mathrm{~mm}$

$$
h_{t}=1.67 \times\left[\frac{12}{60}\right]^{\frac{4}{3}} \times \frac{1.5^{2}}{2 x 9.81} \sin 60=0.019 \mathrm{~m}
$$

Turbine

$$
\begin{aligned}
\text { Net Head } & =\text { Gross Head }- \text { Losses } \\
& =30-(0.073+0.517+0.155+0.274+0.019) \\
& =28.96 \mathrm{~m}
\end{aligned}
$$

\section{Power Output $(p)$}


The power output the turbine is given as $(P)$

$P=\eta \rho g Q H_{n}$

$\eta=0.9$

$\rho=1000 \mathrm{~kg} / \mathrm{m}^{3}$

$g=9.81 \mathrm{~m} / \mathrm{s}^{2}$

$Q=31.8 \mathrm{~m}^{3} / \mathrm{s}$

$H_{n}=28.86 \mathrm{~m}$

$$
P=0.9 \times 1000 \times 9.81 \times 31.8 \times 28.96=8.13 \mathrm{MW}
$$

Specific Speed $\left(n_{Q E}\right)$

The rotational speed of a Kaplan turbine is given by equation

$$
\begin{gathered}
n_{Q E}=\frac{2.294}{H_{n}^{0.486}} \\
n_{Q E}=\frac{2.294}{28.86^{0.486}}=0.5 \mathrm{~s}^{-1}
\end{gathered}
$$

\section{Rotational Speed ( $n$ )}

The rotational speed is calculated from equation below

$$
\begin{gathered}
n_{Q E}=\frac{n \sqrt{Q}}{E^{\frac{3}{4}}} \\
E=H_{n} \times g=28.96 \times 9.81=284.09 \mathrm{~m}^{2} / \mathrm{s}^{2} \\
n=\frac{n_{Q E} E^{\frac{3}{4}}}{\sqrt{Q}}=\frac{0.5 \times 284.09^{\frac{3}{4}}}{\sqrt{31.8}}=6.1 \mathrm{~s}^{-1}
\end{gathered}
$$

\section{Runway Maximum Speed}

The runway maximum speed for a Kaplan turbine is given as:

$$
3.2 \times n=3.2 \times 6.1=19.52 \mathrm{~s}^{-1}
$$

\section{Runner diameter $\left(D_{e}\right)$}

$$
\begin{gathered}
D_{e}=84.5\left(0.79+1.602 n_{Q E}\right) \frac{\sqrt{H_{n}}}{60 n} \\
D_{e}=84.5(0.79+1.602 \times 0.5) \frac{\sqrt{28.96}}{60 \times 6.1}=1.98 \mathrm{~m}
\end{gathered}
$$

Hub diameter $\left(D_{i}\right)$

$$
\begin{gathered}
D_{i}=\left(0.25+\frac{0.0951}{n_{Q E}}\right) D_{e} \\
D_{i}=\left(0.25+\frac{0.0951}{0.5}\right) \times 1.98=0.87 \mathrm{~m}
\end{gathered}
$$

\section{Cavitation coefficient $(\sigma)$}

$$
\sigma=1.541 \times n_{Q E}^{1.46}+\frac{v^{2}}{2 g H_{n}}
$$




$$
\sigma=1.541 \times 0.5^{1.46}+\frac{5.99^{2}}{2 \times 9.81 \times 28.96}=0.623
$$

\section{Suction head $\left(H_{s}\right)$}

$$
H_{s}=\frac{P_{a t m}-P_{v}}{\rho g}+\frac{v^{2}}{2 g}-\sigma H_{n}
$$

$P_{\text {atm }}=98,000 \mathrm{~Pa}$

$P_{V}=3493.04 \mathrm{~Pa}$

$$
H_{s}=\frac{98000-3493.04}{1000 \times 9.81}+\frac{5.99^{2}}{2 \times 9.81}-0.623 \times 28.96=-6.577 \mathrm{~m}
$$

\section{Cost Analysis}

Cost analysis was carried out using the fundamental equations [19].

\section{Annual Energy Output (E)}

The annual energy output is given as a function of

$$
E=f\left(Q_{\text {median }}, H_{n}, \eta_{\text {turbine }}, \eta_{\text {generator }}, \eta_{\text {gearbox }}, \eta_{\text {transformer }}, \gamma, h\right)
$$

where;

$Q_{\text {median }}=$ flow in $\mathrm{m}^{3} / \mathrm{s}$ for incremental steps on the flow duration curve

$H_{n}=$ Specific net head

$\eta_{\text {turbine }}=$ turbine efficiency

$\eta_{\text {generator }}=$ generator efficiency

$\eta_{\text {gearbox }}=$ gearbox efficiency

$\eta_{\text {transformer }}=$ transformer efficiency

$\gamma=$ specific weight of water

$h=$ number of hours in a year

\section{Annual Energy Generation}

The annual energy generation is given as:

Annual Energy Yield $(\mathrm{kWh})=$ capacity factor $\times$ Power $(\mathrm{kW}) \times$ Hours in a day $\times$ Days in a year

Annual Energy Yield $(\mathrm{kWh})=0.5 \times 8130 \mathrm{~kW} \times 24$ hours $\times 365$ days $=3.6 \times$

\section{$10^{7} \mathrm{kWh}$}

The current rate of electricity in Nigeria is 16.11 per $\mathrm{kWh}$.

Hence, Annual generated revenue $=$ Annual Energy Yield $\times$ Rate

$$
\begin{aligned}
& =3.6 \times 10^{7} \times 16.11 \\
& =579,960,000
\end{aligned}
$$

\section{Results}

Design Head, H: $30 \mathrm{~m}$

Flow Rate, Q: $31.8 \mathrm{~m}^{3} / \mathrm{s}$

Theoretical Power, $\mathrm{P}_{\mathrm{th}}$ : $9.36 \mathrm{MW}$ 


\subsection{Penstock Design}

Material: Polyvinyl Chloride Pipe

Length, $L: 100 \mathrm{~m}$

Diameter, $D: 2.6 \mathrm{~m}$

Minimum thickness, $t_{\min }: 7.7 \mathrm{~mm}$

Penstock thickness, $t .15 \mathrm{~mm}$

Velocity in Penstock, $V: 5.99 \mathrm{~m} / \mathrm{s}$

Head loss at penstock inlet, $h_{i}: 0.073 \mathrm{~m}$

Frictional loss in penstock, $h_{\dot{f}} 0.517 \mathrm{~m}$

Head loss at bends, $h_{b}: 0.155 \mathrm{~m}$

Loss at gate valve, $h_{r}: 0.274 \mathrm{~m}$

Pressure wave velocity, c. $125.49 \mathrm{~m} / \mathrm{s}$

Critical time, $T: 1.59 \mathrm{sec}$

Surge pressure in penstock, $P_{s}: 51.22 \mathrm{~m}$

\subsubsection{Trash Rack}

Configuration: Type 1

Approach velocity to trash rack, $V_{0}: 1.5 \mathrm{~m} / \mathrm{s}$

Inclination to the horizontal, $\alpha: 60^{\circ}$

Bar Spacing, $b: 70 \mathrm{~mm}$

Bar thickness, $t_{b}: 12 \mathrm{~mm}$

Bar width, a: $60 \mathrm{~mm}$

Total surface area, $S: 62 \mathrm{~m}^{2}$

Head loss through trash rack, $h_{i} 0.015 \mathrm{~m}$

\subsubsection{Turbine}

Selected turbine: Kaplan

Power output: $8.13 \mathrm{MW}$

Rotational speed: $6.1 \mathrm{~s}^{-1}$

Specific speed: 0.5

Runway Maximum Speed: $19.52 \mathrm{~s}^{-1}$

Runner diameter: $1.98 \mathrm{~m}$

Hub diameter: $0.87 \mathrm{~m}$

Cavitation coefficient: 0.623 Suction head: $-6.577 \mathrm{~m}$

\subsubsection{Estimated Cost}

Preparation of Site: 2,000,000

Civil Works: 6,000,000

Penstock: 15,660,000

Control System: $\$ 500,000$

Turbine: 8,439,000

Generator: $\$ 4,000,000$

Exciter: $3,700,000$

Protection System: 700,000

DC Emergency Supply: 1,000,000 
Transformer: 15,000,000

Installation: $4,500,000$

Total Cost: 61,499,000

Miscellaneous/Unforeseen expenses: 3\%

$$
=1,844,970
$$

Total Cost: $133,343,970$

\subsubsection{Annual Revenue}

The annual revenue is defined as the gross average annual energy output multiplied by the estimated cost of energy per kilowatt (kw/hr) minus the cost incurred as a result of downtime. Downtime is any period the SHP is not functioning either due to maintenance reasons or shortage of water.

Annual Energy Output: $3.6 \times 10^{7}$ Kilowatt hour

Estimated Annual Revenue: 579,960,000

Estimated Yearly Cost of Maintenance: 500,000

\section{Conclusions and Recommendations}

In conclusion, this work has been able to establish that Ikere gorge Dam in Nigeria is a feasible site for a small hydropower plant. Small hydropower plant capable of supplying electricity for a small community using the gorge as a case study has also been designed. Estimated power generation capacity of the designed SHP is $9.36 \mathrm{MW}$. While the estimated total cost of the plant is $63,343,970$, the plant annual deliverable expected revenue estimated is $579,960,000$ with annual power yield of $3.6 \times 10^{7} \mathrm{kWh} / \mathrm{yr}$.

\section{Recommendations}

It is clear that adoption of small hydropower schemes is a viable source towards increasing the power generation capacity of Nigeria. However, the underdevelopment in small hydropower is tilted towards certain governmental policies and their implementation than towards the unavailability of the technology. As a result, the following recommendations are made with regards to small hydropower. In order to reduce the overall cost of purchasing SHP components, local manufacturing capacity needs to be sorted after, encouraged and tested. Deregulation in the upstream and downstream sectors, such as private investors, are encouraged to invest in power generation.

\section{Conflicts of Interest}

The authors declare no conflicts of interest regarding the publication of this paper.

\section{References}

[1] Ikuponisi, F.S. (2004) Status of Renewable Energy in Nigeria. A Background Brief for an International Conference on Making Renewable Energy a Reality.

[2] Sambo, A.S. (2005) Renewable Energy for Rural Development. The Nigerian Perspective. 
[3] ECN-UNDP RE Master Plan (2005) International Workshop on Renewable Energy Master Plan.

[4] Laguna, M., Upadhyay, D. and Taylor, S. (2006) Renewable Energy World. Small Hydro Flowing to the East, January-February.

[5] Adigüzel, F. and Tutus, A. (2002) Small Hydroelectric Power Plants in Turkey. Paper Presented in HYDRO: Development, Management, Performance, Kiris, Antalya, 283-293.

[6] US Department of Energy (2008) Annual FOIA Report.

https://www.energy.gov/management/.../us

[7] Hydropower Roadmap (2012)

https://www.scripd.com/document/166086912/2012-Hydropower-Roadmap

[8] Baird, S. (2006) The Future of Electricity. Electricity Today, 18, 9-11.

[9] International Energy Agency. (2012) Technology Roadmap: Hydropower.

[10] Linsley, R.K., Franzini, J.B., Freyberg, D.L. and Tchobanoglous, G. (1992) Water Resources Engineering. McGraw-Hill, Inc., Singapore.

[11] Taylor, S., Upadhyay, D. and Laguna, M. (2006) Flowing to the East: Small Hydro in Developing Countries. Renewable Energy World, 126-131.

[12] Dragu, C., Sels, T. and Belmans, R. (2001) Small Hydropower State of the Art and Applications. International Conference Power Generation and Sustainable Development, Liege, July 2001, 265-270.

[13] Pelikan, B., Papetti, L. and Laguna, M. (2006) Keeping It Clean Environmental Integration of Small Hydropower. Renewable Energy World, 74-79.

[14] Paish, O. (2002) Small Hydro Power: Technology and Current Status. Renewable and Sustainable Energy Reviews, 6, 537-556. https://doi.org/10.1016/S1364-0321(02)00006-0

[15] Sule, B.F. (2010) SHP Technology and Overview of SHP Potential in Nigeria, ECN Comprehensive Staff Induction, 2010.

[16] NASENI. (2011) National Agency for Science and Engineering Infrastructure. Nigerian Society of Engineering Journal.

[17] UNIDO. (2006) The Nigerian Capacity to Host the Regional Centre for SHP, UNIDO Regional Center for Small hydro Power, Abuja, Nigeria. http://www.smallhydroworld.org/countries/Nigeria/detail/?type $=67425$

[18] Kumar, A.T., Schei, A., Ahenkorah, R., Caceres Rodriguez, J.-M., Devernay, M., Freitas, D. and Hall, Å. (2011) Hydropower. IPCC Special Report on Renewable Energy sources and Climate Mitigation. Cambridge University Press, Cambridge, United Kingdom and New York, NY, USA.

[19] Kadner, S., Zwickel, T., Eickemeier, P., Hansen, G., Schlömer, S. and von Stechow, C. (2011) Hydropower. IPCC Special Report on Renewable Energy Sources and Climate Mitigation. Cambridge University Press, Cambridge, United Kingdom and New York, NY, USA. 